DEPARTAMENTO DE PSICOLOGIA

Curso de Especialização em Psicologia e Saúde

\title{
CLASSE POPULAR E SAÚDE: \\ O CUIDADO E O INVESTIMENTO \\ NA CRIANÇA E NO ADOLESCENTE
}

Juliana Mayerhoffer Vieira

Mônica Campioli

Orientadora

Rio de Janeiro, 29 de abril de 2011. 
DEPARTAMENTO DE PSICOLOGIA

Curso de Especialização em Psicologia e Saúde

Juliana Mayerhoffer Vieira

\section{CLASSE POPULAR E SAÚDE: O CUIDADO E O INVESTIMENTO NA CRIANÇA E NO ADOLESCENTE}

Monografia apresentada ao Programa de Pós-Graduação em Psicologia da PUC-Rio como requisito parcial para obtenção do título de Especialista em Psicologia e Saúde. Aprovada pela Comissão Examinadora abaixo assinada.

\section{Mônica Campioli}

Orientadora

Mayla Cosmo

Rio de Janeiro, 29 de abril de 2011

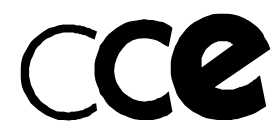

COORDENAÇÃO

Central de

E XTENSÃo 


\section{Agradecimentos}

À minha orientadora, Mônica Campioli, pelo cuidado e atenção no desenvolvimento deste trabalho.

Aos meus pais pelo amor, apoio e investimento no meu crescimento pessoal e profissional.

À minha irmã, Fernanda Mayerhoffer, pela constante dedicação e bom humor.

À Mariana Almeida e Luana Souza, pelo incentivo na elaboração deste trabalho, amizade e parceria profissional.

À Mayla Cosmo, pela supervisão atenciosa dos casos descritos neste trabalho. 


\section{Resumo}

As crenças e costumes dos grupos sociais interferem no modo como seus membros tratam de questões relacionadas à saúde. Partindo deste pressuposto, este trabalho propõe uma reflexão no que tange a classe popular e suas relações, a representação de saúde/doença e o modo como esta é circunscrita socialmente. A partir desta reflexão, busca-se compreender de que modo e através de quais noções e valores os membros da classe popular dão forma e sentido às suas experiências de cuidado da saúde da criança e do adolescente. É possível, assim, compreender a ampla diferença entre a posição ocupada pelo jovem de classe popular e o jovem de outras classes. As crianças de classe popular são geradas sem investimento e planejamento, restringindo, ainda mais, suas possibilidades de alcançar melhores condições de vida. Não se deve, no entanto, buscar que a classe popular seja uma réplica das classes abastadas, com seus modelos de família moderna, mas que seus membros sejam compreendidos e respeitados dentro de sua própria cultura e valores.

Palavras Chave: Classe popular, saúde, infância, adolescência, cuidado. 


\section{Sumário}

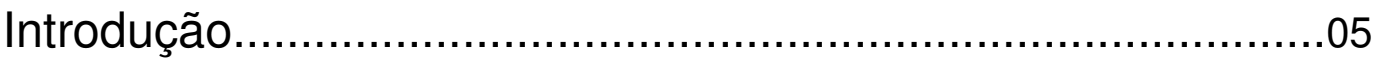

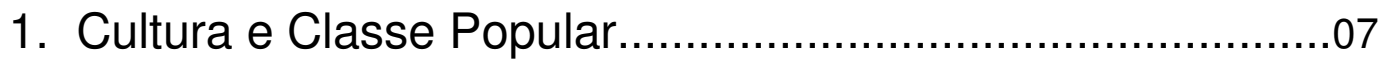

1.1. Classe Popular e Família...........................................10

1.2. Classe Popular e Infância....................................................12

1.3. Projeto de Vida Dentro das Classes......................................14

1.4. A Crítica ao Modelo Evolucionista.........................................15

2. As Representações de Saúde/Doença..............................17

3. Classe popular, Saúde e o Cuidado Infantil.......................26

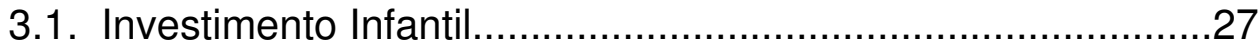

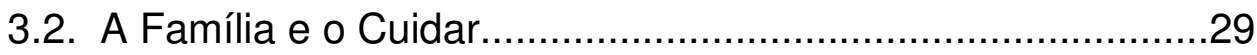

3.3. A Mulher/Mãe e o Cuidar.........................................................

3.4. A Mãe de Classe Popular e a Gravidez na Adolescência......34

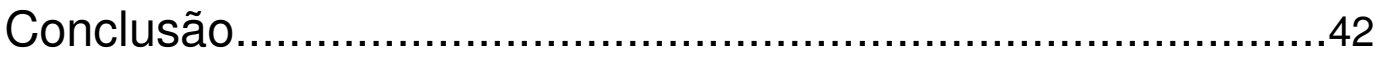

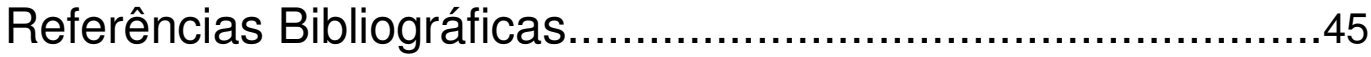




\section{Introdução}

A política do capitalismo neoliberal globalizado resulta na distribuição desigual de renda, aumento do desemprego e da violência, retração das redes sociais, entre outros aspectos, intensificando a pobreza, a exclusão e as desigualdades sociais. Estes fatores socioeconômicos e políticos contribuem para os agravos de saúde da população, formando assim um ciclo vicioso de pobreza, isolamento e adoecimento (Guimarães, 2011).

O estudo dos fenômenos da saúde/doença se insere no princípio de relativização da pessoa e esta relativização advém do processo de comparação entre as culturas (Duarte, 2003). As crenças e costumes interferem no modo como os membros de cada sociedade tratam de questões relacionadas à saúde das suas crianças, como vacinação e alimentação, englobando todos os aspectos do cuidar. Os diagnósticos e tratamentos médicos, do mesmo modo, são influenciados por tal tradição e, em ultima instância, a própria vida de crianças é determinada por costumes em povos mais isolados (Leite e Vasconcellos, 2006).

O presente trabalho busca analisar de que modo e através de quais noções e valores os membros da classe popular dão forma e sentido às suas experiências orgânicas individuais e compreender como, nessas bases, se elabora sua realidade compartilhada coletivamente. A partir da análise da classe popular, suas relações e suas representações de saúde/doença, objetiva-se compreender o cuidado em saúde e investimento na vida da criança e do adolescente dessa classe social.

O interesse pelo tema surgiu a partir da experiência de estágio profissional na pediatria de um hospital municipal de grande porte do Rio de Janeiro onde muitos dos pacientes atendidos pertencem à classe popular. A partir dos atendimentos psicológicos e observações desses pacientes e seus acompanhantes, surgiram diversas perguntas acerca do cuidado e do investimento à saúde das crianças:

- Como ocorre o cuidado em saúde das crianças de classe popular?

- Quais são as expectativas das mães de classe popular na gravidez, desenvolvimento e futuro dos filhos? 
- Quais seriam as repercussões desta forma particular de cuidar no futuro destas crianças?

A complexidade que envolve a vida cotidiana e o enfrentamento das doenças, levando em conta as distintas realidades sociais, geralmente não é aprofundada na formação do profissional de saúde. A diferença substancial entre os elementos que embasam o raciocínio desses profissionais e os diversos grupos populares gera grande dificuldade para que o profissional compreenda as atitudes de seus pacientes, resultando em relações distanciadas e preconceituosas (Leite e Vasconcellos, 2006).

A partir de um amplo entendimento a respeito da saúde e desenvolvimento das crianças brasileiras, e da necessidade de se relativizar e contextualizar conceitos, seria possível uma ação mais efetiva por parte dos profissionais da área da saúde. Seria facilitada, do mesmo modo, a relação equipe médica/paciente e acompanhante de classe popular, tornando possível uma atenção mais adequada.

Esta pesquisa se propõe, portanto, a compreender a relação de cuidado da saúde dos jovens dentro da classe popular. No Capítulo "Classe Popular" será abordado o conceito de cultura e classe, com foco nas características da classe popular, suas relações interpessoais e no modo como tais características contrastam com as classes abastadas. No capítulo seguinte é proposta uma compreensão das representações de saúde/doença, sua relatividade e influência cultural.

No terceiro capítulo é realizada uma análise a respeito do investimento infantil e do cuidar da saúde da criança. Investiga-se de que modo este cuidado se apresenta dentro da classe popular. Busca-se compreender quem são os personagens responsáveis por esse cuidado e de que modo desempenham o seu papel. É abordado o fenômeno da gravidez durante a adolescência característica freqüente dentro dessa classe - analisando suas causas e conseqüências, objetivando contextualizar os conceitos levantados. Ao longo do trabalho, para ilustrar as idéias desenvolvidas, são relatados trechos de atendimentos psicológicos e observações na enfermaria de pediatria. 


\section{Cultura e Classe Popular}

Para que se determine a natureza das relações sociais é fundamental a compreensão da maneira como as pessoas categorizam e atribuem conceitos às suas experiências (Oliveira e Roazzi, 2007). A idéia de que existe uma produção simbólica e um sistema de símbolos que dão as indicações e contornos de grupos sociais e sociedades é bastante reveladora. Deste modo é possível entender cultura como código e como sistema de comunicação através do qual a vida social se processa e não apenas um repositório estático de hábitos e costumes ou uma coleção de objetos e tradições (Velho, 1987).

De acordo com Oliveira e Roazzi (2007), assim como o parentesco e a organização social, a linguagem é um medidor indispensável na transmissão cultural, uma vez que, através dela, são apreendidas as regras fundamentais da cultura. A linguagem é responsável pela apreensão, transmissão e realização dos conhecimentos e, desta forma, os indivíduos expressam seus comportamentos e dinâmicas socioculturais. Desta forma, é pela linguagem que os elementos simbólicos se relacionam para formar um sistema: as palavras expressam o modo como as pessoas constroem o seu mundo de experiências e seus conceitos, traduzindo a lógica simbólica que determina as ações sociais.

Os indivíduos, dentro de suas respectivas sociedades, categorizam, classificam, conceituam e nomeiam os fatos e as outras pessoas para se comunicarem. Ao mesmo tempo em que atribuem uma lógica, compreendem suas próprias experiências e o mundo que as cercam. Assim, criam suas experiências a partir da forma pela qual ela é comunicada. Desta perspectiva, pode-se considerar a cultura como uma linguagem em sentido amplo (op. cit.).

Segundo Gomes, Mendonça e Pontes (2002), as representações coletivas não são apenas o produto de uma imensa cooperação ocorrida em um determinado espaço. Estão, também, relacionadas ao acúmulo de experiências atravessadas por longas séries de gerações. Gutierrez e Minayo (2011) afirmam que a cultura, enquanto elemento integrador, une fenômenos que se apresentam em vários níveis: individual, social e histórico. A cultura é uma interseção de 
trajetórias e transições no desenvolvimento de indivíduos e famílias com o mundo mais amplo das mudanças sócio-históricas.

De acordo com Berger e Luckmann (1966 apud Oliveira e Roazzi, 2007), a construção da identidade social dos indivíduos se processa na vida cotidiana, por meio do cumprimento de tarefas que compõem suas rotinas e papéis instituídos e que, por sua vez, vão manter a realidade que é internalizada.

$\mathrm{Na}$ relação com o outro, as pessoas constroem seus códigos de identificação e a partir das trocas sociais são atribuídos significados para a auto definição e definição do outro. Isto ocorre através de um processo dinâmico de construção do eu, composto de elementos individuais e sociais que se expressam na medida em que há a vivência de um sentimento de pertença. É a partir da vida cotidiana que os indivíduos pensam e repensam, reformulam e reconstroem suas noções de entendimento, seus padrões de comportamento e seus modelos explicativos do que é considerado saúde/doença, normal/anormal, masculino/feminino (Oliveira e Roazzi, 2007).

Os símbolos construídos pelo homem para dar significado às experiências vividas baseiam-se em princípios construídos dentro de uma realidade social empírica. Ao longo do tempo, em sua prática, o homem capta informações, articula sentidos e produz símbolos para realizar suas trocas. Por entender que a cultura é essencialmente um sistema simbólico ou uma configuração de sistemas simbólicos, pode-se afirmar que a dimensão simbólica dos seres humanos determina as ações sociais, na medida em que atribui e organiza os significados aos fenômenos (op. cit.).

Velho (1987) ressalta que os indivíduos participam diferencialmente de códigos mais restritos ou mais universalizantes, sendo essa diferença o resultado das experiências vivenciadas a partir da classe social especifica a que pertence.

Para definir o conceito de classe social, Barros (1986) reporta-se a elementos centrais. Para a autora, as classes são grandes grupos de pessoas que diferem umas das outras pelo lugar ocupado por elas em um sistema historicamente determinado de produção social. Diferem também por sua relação com os meios de produção, por seu papel na organização social do trabalho e, por conseqüência, pelas dimensões e método de adquirir a parcela de riqueza social que disponham. As classes são grupos de pessoas onde uma 
pode se apropriar do trabalho de outra, devido a lugares diferentes que ocupam dentro do sistema definido de economia social.

Assim, para que seja feita uma análise real de determinada classe social torna-se fundamental olhar para além dos indicadores socioeconômicos como profissão, renda e escolaridade. Guimarães (2011) propõe que para compreender as classes baixas a sua complexidade não seja encarada como um problema estritamente econômico, sendo, acima de tudo, um problema social.

O fenômeno da pobreza é vinculado principalmente à insuficiência de renda ou ao desprovimento de necessidades básicas. A condição em que vivem as classes baixas é resumida a uma situação na qual as necessidades não são atendidas de forma adequada, incorporando, portanto, além das necessidades básicas como alimentação, outras necessidades humanas como educação, saneamento e habitação. Compreende-se pobreza e desigualdade como duas faces de um mesmo problema, relacionadas diretamente com o contexto social no qual as pessoas estão inseridas. Em última instância, estar em situação de pobreza significa não dispor de meios para operar adequadamente dentro do grupo social em que se vive (Rocha, 2003 apud Guimarães, 2011).

Assim, a ênfase no caráter relativo da noção de pobreza parece mais adequada, pois implica a definição de necessidades a serem satisfeitas em razão do modo de vida de cada sociedade. Esta noção difere da idéia de "pobreza absoluta" que, por sua vez, está vinculada à sobrevivência física e, portanto, ao não atendimento das necessidades vinculadas ao mínimo vital (Guimarães, 2011).

Guimarães (2011), ao tratar da questão da classe popular, ressalta que o que está em foco não são apenas os problemas de desenvolvimento e de recursos econômicos, mas, acima de tudo, de interesses, níveis de prioridade, graus de desigualdade e de organização política e social. Como conseqüência direta da situação de precariedade, tornam-se evidentes sintomas como desemprego, desnutrição e fome, além do aparecimento de novas doenças e o reaparecimento ou aumento de incidência de antigas.

Ao analisar o modo de vida de indivíduos inseridos na classe popular, observa-se o aumento do número de pessoas morando em uma mesma casa e em barracos construídos em lugares sem saneamento ou segurança. Em virtude 
do espaço reduzido das habitações, muitas com apenas um cômodo pequeno, as crianças dormem amontoadas e em locais inseguros, como próximas ao fogão. Em algumas casas as famílias são obrigadas a dividir o espaço com ratos, aquelas que possuem berços precisam suspendê-los no alto dos barracos para evitar que os bebês sejam mordidos enquanto dormem. Alguns não têm sequer acesso a banheiros, utilizando banheiros coletivos e/ou improvisando na área externa da casa. Em algumas moradias existem valas de esgoto abertas na entrada e no seu interior. Tais condições inapropriadas de habitação e higiene culminam no surgimento e progressão de doenças (Guimarães, 2011).

A violência também é freqüente na luta pela sobrevivência dentro da classe popular. O abuso e dependência de álcool e outras drogas muitas vezes se constitui numa possível resposta para pessoas que, em vão, buscam vínculos e o reconhecimento de que possuem valor e uma vida interior - como as pessoas de outras classes sociais - com sonhos, desejos e expectativas. Entretanto, essa forma de responder aos anseios de visibilidade e inserção social acarreta mais violência, em especial no âmbito das relações familiares. $O$ alto índice de alcoolismo, inclusive entre adolescentes, e o consumo de cocaína e crack pelos jovens, aos quais tradicionalmente fica o encargo de cuidar dos irmãos mais novos, levantam a hipótese de que algumas crianças ficam sem assistência. É possível considerar, paralelamente, freqüentes casos de abandono e omissão por parte dos pais e responsáveis (op. cit.).

\section{1}

\section{Classe Popular e Família}

Faz parte do senso comum acadêmico o reconhecimento da multiplicidade das formas e sentidos de família. A família, de acordo com Foucault (1980 apud Duarte, 1995), é um fenômeno social de origem recente. Entretanto, de modo geral, o conceito de família engloba o sistema de localidade ou residência, a corporatividade e o sistema de atitudes (Fonseca, 2000).

A família, no ocidente moderno, tem como código universal a relação de parentesco. Assim, a consanguinidade imposta pelas condições específicas da 
reprodução dos seres humanos, conecta-se com a afinidade, imposta pela imprescindibilidade da troca social (Fonseca, 2000)

Duarte (1995) observa, no entanto, que o formato de família difere muito entre as elites e classes populares e ao longo dos momentos históricos. modelo familiar de classe popular se distingue claramente das classes médias, havendo prevalência de uniões consensuais, frequência de famílias compostas de mães solteiras e alta taxa de instabilidade conjugal.

A penúria a que se encontra exposto este grupo familiar, torna-se ainda maior quando a mulher/mãe é solteira ou abandonada pelo marido, o que frequentemente ocorre. Nestes casos, a mulher e seus filhos são ainda mais sobrecarregados (Tavares, 2010).

A família de classe popular revela-se, na verdade, uma instituição muito diversa daquela que comumente é tida como dominante. Ela conjuga a dimensão genérica do parentesco com a dimensão operacional do grupo domestico, se assemelha, neste sentido, à família camponesa (Duarte, 1995).

De acordo com muitos historiadores, o ideal de família moderna, constituído em torno do século XVII, é caracterizado pela livre escolha de um cônjuge, incorporação do amor romântico ao laço conjugal e pelo ideal de aconchego na unidade doméstica. O ambiente doméstico proporciona, assim, um refúgio para as pressões do mundo público, enquanto, paralelamente, surge 0 sentimento de valorização e centralização dos filhos, tendo a figura materna como sua principal socializadora. Tal quadro mostra-se por muitas vezes incompatível com o que se observa nas famílias e relações entre pais e filhos de classe popular (Fonseca, 1995).

Tavares (2010) relata uma série de padrões que permeiam a problemática das relações familiares de classe popular e que o afastam dos ideais de família moderna descritos. De acordo com a autora o chefe de família desta classe freqüentemente falha em, com seu trabalho, transformar o cotidiano de fome e extrema miséria do seu grupo familiar, falhando ao prover um ambiente acolhedor. Como consequência deste padrão, existe uma tendência geral em buscar no abuso da bebida alcoólica um alívio temporário ou fuga desta realidade. Enquanto isso, no espaço doméstico, a legitimação de sua autoridade 
é confrontada e, como se para reafirmá-la, o chefe de família muitas vezes recorre à violência.

A violência se reproduz nas relações familiares e, não raro, manifesta-se no convívio entre mãe e filhos. Os filhos tornam-se alvos de agressões ao mesmo tempo em que se sentem responsáveis pela proteção da mãe, que por sua vez também sofre violência. Dessa forma, na memória afetiva dos jovens, a imagem da proteção parental dilui-se. Surge nas jovens mulheres o sentimento de resignação ao mesmo tempo em que inicia um trabalho precocemente para fornecer ajuda financeira à mãe e irmãos (Tavares, 2010)

\section{2}

\section{Classe Popular e Infância}

Calligaris (1996) defende que o lugar ocupado pelas crianças em uma determinada sociedade é crucial. Por serem muitas vezes representantes de projeções, as crianças revelam imediatamente o momento e o estado de uma cultura.

Partindo desta visão, o sentimento de afeto em relação às crianças não pode ser considerado natural. Apesar de ser clara a necessidade de cuidados e atenção ao ser humano, sem os quais a espécie se perderia em nossa história passada, não dedicamos todos, às crianças, o mesmo afeto no que se refere ao modo e à intensidade (op. cit.).

Os adultos, membros da família moderna, esperam que seja fornecida pelas crianças a imagem de plenitude e felicidade e, por isso as protegem, cuidam e satisfazem; o mesmo não ocorre em todos os grupos sociais (op. cit.).

A infância é uma invenção moderna e esse tempo separado da vida adulta e protegido pelo "amor parental" surgiu em nossa cultura há apenas dois séculos, quando o individualismo finalmente triunfou no ocidente (Aries, 1978). Os ideais de amor materno e de 'domesticalidade' conjugal só se configuraram na Europa em torno do século XVII, tendo evoluído em função de educação escolar e de certa divisão do trabalho que deixava a mãe disponível para atender as necessidades primárias de seus filhos. É possível que, no Brasil, em razão de um 
conjunto radicalmente diferente de circunstâncias, a família em grupos populares não tenha evoluído segundo os padrões europeus. A unidade mãe-pai-filhos não se apresenta bem delimitada. As necessidades, tanto materiais, quanto afetivas, de seus membros são, com freqüência, satisfeitas por pessoas alheias a esse núcleo. A unidade familiar é porosa, perpassada por outros grupos, como vizinhos e parentes, e é regida por uma dinâmica social que pouco tem em comum com o modelo moderno (Fonseca, 1990).

A partir da idéia de que o lugar da criança na família se adapta ao quadro socioeconômico, compreende-se que a fluidez dos limites das unidades domésticas e a instabilidade conjugal também contribuem para peculiaridades na relação família/infância em grupos populares. Tavares (2010) elucida que nas famílias populares, numerosas na quantidade de filhos, constantemente ameaçadas pelo desemprego, a urgência é assegurar o sustento da unidade doméstica. Assim, fica registrada na memória das crianças a ausência de uma infância como é conhecida pelas outras camadas sociais (Fonseca, 1990).

A ausência de infância encontra-se marcada por um curto espaço de tempo dedicado à escola, por falta de orientação e pouco estudo. No caso das meninas, desde muito jovens seu principal dever é ajudar nas tarefas domésticas e muitas cuidam dos irmãos mais novos. Em determinadas famílias, os pais utilizam ainda de violência na cobrança das realizações de tais tarefas. Diante da dura rotina imposta, "adultiza-se" a criança, sobrando-Ihe pouco tempo para o lazer e outras atividades compreendidas como adequadas à infância (Tavares, 2010).

A vida de muitos jovens de classe popular pode ser resumida a uma convivência restrita com a figura paterna, ausência de diálogo familiar, rudeza de olhares e gestos, frequentemente acompanhados por xingamentos e agressões físicas, dirigidas a si, às suas mães e irmãos. Diante da dura realidade em que vivem, resta pouco lugar para outras fomes: estudar e brincar torna-se algo secundário, pois a prioridade é sobreviver (op. cit.).

Nas observações dos pacientes e acompanhantes da enfermaria da pediatria, as características de família citadas anteriormente e o lugar ocupado pela criança dentro dessa classe social são claramente demonstrados. Comumente os jovens não moram com seus pais, muitos tendo com eles apena um contato restrito. Com freqüência o acompanhante não se apresenta e, em 
outros casos, crianças são abandonadas pelas mães após um curto período de tempo de internação. A fala de um menino de treze anos é ilustrativa:

"Não sei dizer onde está a minha mãe e nem qual foi a ultima vez que estive com ela(...). Mudo sempre de casa em casa já que ninguém quer ficar comigo. Me mandam ficar com outra pessoa porque dou muito trabalho, e dou mesmo, não gosto de obedecer. Não falo direito com meu pai, ele não é um cara legal. (...) não vou à escola, já que ninguém manda em mim e eu não quero ir. Prefiro fazer as minhas coisas, prefiro ficar com os meus amigos."

\section{3}

\section{Projeto de Vida Dentro da Sociedade de Classes}

O projeto de vida diz respeito ao conjunto de planos e diretrizes básicas que determinarão o rumo que o individuo pretende tomar no futuro. De acordo com Velho (1987), a noção de projeto procura dar conta da margem relativa de escolha que indivíduos e grupos têm em determinado momento histórico de uma sociedade. A possibilidade da existência de projetos individuais está vinculada a contextos sócio-culturais específicos.

O projeto não é, portanto, um fenômeno puramente interno e subjetivo, formula-se e é elaborado dentro de um campo de possibilidades, circunscrito histórica e culturalmente, tanto em termos da própria noção de individuo, como dos temas, prioridades e paradigmas culturais existentes. Em qualquer cultura há um repertório limitado de preocupações e problemas centrais dominantes, existindo uma linguagem e um código através dos quais os projetos podem ser verbalizados com maior ou menor potencial de comunicação (op. cit.).

As emoções de um individuo estão ligadas, são matéria-prima e constituem seu projeto. Há sentimentos e idéias valorizadas, toleradas e condenadas dentro de um grupo ou sociedade, havendo, portanto, maiores e menores possibilidades de viabilizá-los e efetivá-los. Desejos inadequados são limitados e balizados pelas normas mandantes dentro de determinada classe. Os padrões de normalidade legitimarão ou não, dentro de cada situação, as condutas e ações individuais. Um código ético-moral define o errado e impróprio que pode haver nos homens e nas suas condutas e interações (op. cit.). 
Em uma sociedade complexa moderna, os mapas de orientação para a vida social são particularmente ambíguos, tortuosos e contraditórios. A construção da identidade e a elaboração de projetos individuais são feitas dentro de um contexto em que diferentes "mundos" ou esferas da vida social se interpenetram, se misturam e muitas vezes entram em conflito (Velho, 1987).

\section{4}

\section{A Crítica ao Modelo Evolucionista}

No senso comum, tendo na família moderna a norma implícita contra a qual se tende a medir todos os comportamentos, a lógica evolucionista revela-se persistente. Apressa-se a supor que, uma vez que os integrantes da classe média não podem imaginar outro modelo que não além da família conjugal, os grupos populares tampouco conseguiriam. Este modo de pensar não persiste apenas entre os conservadores, mesmo entre os progressistas o desejo de ver classes trabalhadoras possuírem o mesmo conforto material e os mesmos direitos civis que as abastadas, freqüentemente desencadeia para a suposição de que devem também compartilhar do mesmo sistema de valores (Fonseca, 1995).

Fonseca (1995) faz uma crítica ao habito persistente de, no lugar de se procurar compreender a dinâmica histórica que orienta as práticas de cada grupo, contentam-se em perguntar: "Por que todo mundo não se comporta como as classes abastadas (subentendido, "avançadas") da sociedade?". A autora defende que a família moderna não deveria ser pensada como uma meta a ser alcançada. A constituição de outro modelo de convivência não significa um vácuo cultural; as formas familiares em grupos populares, longe de serem uma etapa anterior a família moderna, são formas definidas e consolidadas.

Duarte, Barsted e Taulais (1993) acreditam haver um acúmulo de malentendidos no que tange a percepção das diferenças entre a cultura dominante e a da classe popular. Para esclarecer, o autor propõe duas hipóteses: uma em que as classes subalternas teriam uma cultura que poderia ser compreendida como uma subcultura. Essa subcultura não manteria uma relação igualitária com a cultura das classes dominantes, mas não seria tampouco uma mera sobrevivência arcaica ou reflexo diluído e empobrecido do presente. Supõe-se que esta subcultura teria uma lógica própria, por mais insólita e ilegítima que 
pareça, já que sem ela, nenhuma significação e, portanto, nenhuma vivência seria possível. A segunda hipótese compreende a cultura da classe popular como sendo diferente da cultura dominante no sentido amplo e verdadeiramente contrastante.

Guimarães (2011), paralelamente, faz uma crítica ao olhar da mídia sobre as classes subalternas, que em sua opinião julgam os indivíduos como "pessoas que não valem a pena", contribuindo para um sentimento de menos-valia dentro dos membros dessas classes. A favela é apresentada como lugar de bandido ou "de pessoas miseráveis que servem pra nada". Apenas raramente é evidenciada a luta cotidiana por uma vida digna, a criatividade para superar os problemas, a alegria e até mesmo a dor dos que vivem neste espaço. Pelo contrário, sinalizase que o local é tão perigoso que não se pode andar pelas ruas, fazendo, dessa forma, o retrato de um local de exclusão social.

Por séculos o discurso das classes privilegiadas sobre o comportamento dos pobres oscila entre a compaixão e a condenação indignada. Enquanto pesquisadores vão longe para encontrar povos exóticos e compreender a cultura de diferentes tribos, os costumes das classes subalternas próximas são considerados apenas para facilitar intervenções políticas. Em nossas favelas raramente reconhecemos uma cultura digna de interesse quando não há distanciamento étnico ou histórico. Por mais que com facilidade admita-se que os pobres sejam diferentes, esta diferença é interpretada como forma degenerada ou patológica da organização social da classe dominante. Quando o diferente esta próximo, as observações a respeito são carregadas de termos como "violência", "promiscuidade" e "famílias desestruturadas". Relativizar as práticas de pessoas que compartilham do mesmo universo torna-se uma tarefa difícil uma vez que, obrigatoriamente, questionam-se os próprios valores e admitem-se as contradições de um sistema político e econômico que cria subgrupos com interesses quase opostos (Fonseca, 2000).

Esta abordagem não busca valorizar certas dinâmicas em detrimento de outras, mas procura olhar de forma realista para as diferenças culturais que existem no seio da sociedade de classes. Significa explorar o terreno que separa um individuo do outro na esperança de criar vias mais eficazes de compreensão e comunicação (op. cit.). 


\section{As Representações de Saúde/Doença}

Desde tempos remotos, a humanidade enfrenta a doença como parte de seu cotidiano, desenvolvendo, para tanto, estratégias e noções diversas (Leite e Vasconcellos, 2006).

Um dos grandes desafios perante a situação de sofrimento humano é a necessidade da compreensão dos modos pelos quais as pessoas exprimem os sentidos atribuídos à vivência da situação de doença. Estudos em saúde, sob o prisma sociocultural, reconhecem que a doença se constitui de significado. Enquanto categoria de entendimento, a doença pode ser definida como o conjunto de sensações ou sintomas, físicos ou mentais, que são organizados em uma totalidade dotada de sentidos e que tem sua construção no processo de socialização (Oliveira e Roazzi, 2007).

A literatura registra diversos modos de olhar para a doença, assim como diversas interpretações sobre o sentir-se doente. De modo geral, há uma tendência em construir 'modelos' com os quais é possível explicar as relações que os indivíduos fazem com as crenças em saúde. A forma pela qual os indivíduos de uma dada sociedade situam-se em relação à doença, ou como a percebem, é tema reconhecido como de fundamental importância para o estudo social das enfermidades e das formas de lidar com elas (Leite e Vasconcellos, 2006).

São numerosos os trabalhos que procuram compreender a dinâmica das classificações, instituições e serviços. Embora cubram um amplo leque de focos etnográficos, todos têm em comum a disposição em esclarecer como se processa essa dinâmica do contraste entre a racionalização biomédica e as diversas dimensões na vivência dos eventos da saúde/doença (Duarte, 2003).

Alves e Rabelo (1999 apud Leite e Vasconcellos, 2006) afirmam que a doença é a experiência de mal-estar, não sendo necessariamente um problema biológico, o que pontua o caráter pessoal e particular dessa experiência. Para estes autores, o 'mal-estar' torna-se doença quando é transformado em objeto socialmente aceito de conhecimento e intervenção, e é real porque se origina no mundo do senso comum. Para Leite e Vasconcellos (2006) a doença é a 
resposta subjetiva do paciente, e de todos os que o cercam, ao seu mal-estar. Compreender a doença significa estender o olhar sobre o sujeito e sobre o campo de interações entre indivíduos, grupos, instituições e cultura.

"Claramente delineada pela interpretação das ações enquanto construtos sociais e não individuais, a proposta de se olhar para as interações sociais na busca de compreender os cuidados de saúde é bem justificada na própria compreensão mais corrente da doença, enquanto fenômeno de dimensão social, como exposto anteriormente. O próprio reconhecimento da ocorrência de uma doença é compartilhado com a sociedade, assim como o papel de enfermo, a legitimação da doença e das formas de tratá-la. Reconhecer que as interações sociais são fundamentais para a compreensão dos cuidados de saúde, sem dúvida, é uma grande contribuição dos estudos de redes sociais e saúde." (Leite e Vasconcellos, 2006, p. 118)

A experiência da saúde e da doença interpela a identidade pessoal, impondo ações e reações mobilizadoras de sentido. $O$ fato de serem elas consultas, exames ou intervenções médicas põe em cena as diversas e complexas significações e reações do sujeito inserido em seu contexto (Duarte, 2003).

Gomes, Mendonça e Pontes (2002) discorrem a respeito das representações de doença fazendo um paralelo com as palavras utilizadas para designar tal conceito em outros idiomas. Laplantine (1991 apud Gomes, Mendonça e Pontes, 2002) chama atenção para o fato da língua francesa só dispor de um vocábulo: maladie, para exprimir doença; enquanto na língua inglesa há três expressões: disease, a doença tal como ela é apreendida pelo conhecimento médico; illness, a doença como é experimentada pelo doente e sickness, um estado muito menos grave e mais incerto que o precedente de maneira mais geral, o mal-estar.

Leite e Vasconcellos (2006) também ressaltam a importância das diferentes dimensões da doença, que pode ser expressa por diferentes designações. A enfermidade (disease) representa o que o órgão tem, a doença (illness) representa o que o doente tem. Podemos acrescentar, ainda, a idéia de que se considera doente (sickness) aquele que o meio ou a sociedade vê como doente. 
Gomes, Mendonça e Pontes (2002), por outro lado, apóiam a importância de entender o estado de doença sem, contudo, estabelecermos dicotomia entre os pontos de vista de ser uma experiência subjetiva ou um comportamento sócio-cultural. Os autores empregam o termo enfermidade como reflexo da combinação de aspectos da experiência dos indivíduos e situações sócioculturais.

Leite e Vasconcellos (2006) articulam duas maneiras de se definir a vivência da enfermidade: a "doença processo" e a "doença experiência". A primeira refere-se às anormalidades de funcionamento de órgãos ou sistemas, e a segunda, à experiência subjetiva de mal-estar sentido pelo doente.

Gomes, Mendonça e Pontes (2002) formam uma análise similar, onde destaca a concepção de doença englobando dois aspectos: doença-sujeito e doença-sociedade, refletindo, respectivamente, a experiência subjetiva do doente e comportamentos sócio-culturais ligados à doença.

Assim, observa-se que a doença, tal como é percebida pelo doente, não se refere apenas ao processo patológico no sentido biomédico do termo. Considera-se que ela conjuga normas, valores e expectativas, tanto individuais como coletivas, e se expressa sob formas específicas de pensar e agir. A definição de doença não inclui somente a experiência pessoal do problema de saúde, mas também o significado que cada indivíduo confere a ela. Os mesmos sintomas ou enfermidades podem ser interpretados de maneiras completamente diferentes por indivíduos de culturas diferentes ou em contextos diferentes. A doença está, portanto, intimamente relacionada à cultura (Leite e Vasconcellos, 2006; Ressel, 2009).

"Todo ser humano vivendo em sociedade tem dois aspectos: ele é individuo, mas também é pessoa. Como individuo, ele é um organismo biológico, manifesta ações e reações fisiológicas e psicológicas, processos e mudanças; o ser humano como pessoa é um complexo de relações sociais. $O$ individuo se apresenta apenas em sua condição de instancia "infra-social", com mero substrato concreto para a imposição do estatuto social. A pessoa é a unidade investida de significação." (Radcliffe-Brown, 1973 apud Duarte, 2003 p. 175)

A linguagem utilizada para exprimir-se a respeito da saúde e da doença, para interpretar suas causas, manifestações e conseqüências, não é uma linguagem do corpo, mas uma linguagem do individuo em relação à sociedade 
(Adam e Herzlich, 2001). Alicerçando-se nestas premissas, Ressel (2009) também entende que a compreensão de saúde e doença deve estar associada às significações culturais de cada ser humano, as quais podem ser modificadas ou adaptadas conforme o meio em que está inserido.

Os diversos grupos sociais constroem noções de saúde, formam categorias de sintomas e nomeiam-na, baseados em princípios próprios que orientam e organizam suas condutas (Langdon, 2010). Assim, a concepção das doenças ou a sua representação é passível de diferentes interpretações, não apenas conforme o contexto social do qual se fala, mas também conforme o lugar e a situação do indivíduo dentro do grupo. O significado e relevância de uma mesma enfermidade pode ser variável, por exemplo, de acordo com hierarquia, função e papeis familiares dentro de um mesmo ambiente social. Desta forma, as sensações, sinais e sintomas corporais ou não-corporais atribuídos às doenças, devem ser lidos de acordo com códigos de linguagem também específicos a quem fala, e que apenas por eles se traduz (Oliveira e Roazzi, 2007).

Gutierrez e Minayo (2011) reforçam a noção de ligação entre as representaçoes individuais de doença e o contexto social ao afirmar que a cultura opera de modo que os elementos cristalizados por ela passam a ser vividos de modo natural, os ensinamentos incorporados dispensam questionamentos e explicações. Somado à essa idéia de naturalização, as práticas de cuidado de saúde são regidas por uma convenção, ou seja, as coisas não precisam ser ditas.

"Desde a aurora da Modernidade emergiu, junto a uma consciência histórica da existência humana, a consciência de que o adoecer é também histórica e socialmente configurado; de que tanto os determinantes do adoecimento quanto os saberes e instrumentos tecnicamente dirigidos a seu controle são fruto do modo socialmente organizado de homens e mulheres relacionarem-se entre si e com seu meio. Por isso, não faz sentido pensar os valores contrafáticos associados à saúde sem a socialidade dessa experiência. Os fatos em função dos quais estes valores são construídos só podem ser compreendidos em sua relação com os contextos de interação de onde emergem, suas mediações simbólicas, culturais, políticas, morais, econômicas e ambientais. As respostas técnicas e políticas ao adoecimento também são o resultado desses mesmos contextos, reclamando o mesmo tipo de compreensão. A distribuição dos recursos para a proteção contra os adoecimentos, para a recuperação a partir deles ou para a minimização de impactos 
negativos sobre a vida, tanto quanto a própria concepção e operação desses recursos, são igualmente produtos da vida social, na qual finalidades e meios são contínua e interativamente reconstruídos." (Ayres, 2004, p. 26)

A cultura fornece os elementos para que os eventos e as práticas do cotidiano relativas à saúde sejam compreendidas e aceitas. É possível observar que antes mesmo do encontro com o médico, o paciente muitas vezes já construiu uma narrativa pessoal sobre o seu problema de saúde ou sobre uma determinada atitude ou ação preventiva. Estas expectativas que o paciente traz sobre a doença e o tratamento podem estar diretamente relacionadas com a aceitação da terapia, pois indicam as interpretações que o paciente já formulou sobre o problema, que pode coincidir ou não com o que o médico propõe (Leite e Vasconcellos, 2006).

A doença, portanto, é um tema extremamente complexo e passível de diferentes leituras que vão da sociologia à medicina, tratando quer de seu caráter individual, fisiológico, quer de seu aspecto cultural ou social. Da mesma forma, são diversas as compreensões dos modos de lidar com a doença, da procura por serviços, das estratégias formuladas no dia-a-dia, para seu enfrentamento (Leite e Vasconcellos, 2006; Langdon, 2010).

Para Adam e Herzlich (2001), frente à sociedade, 'ser saudável' é caracterizado por sua capacidade de resistência física. Parte-se do princípio de que o individuo é saudável e a saúde é basicamente uma responsabilidade pessoal, sendo o estar doente também critério social de atividade ou inatividade. Adoecer significa "parar", ou seja, interromper sua vida profissional e os sintomas são as disfunções orgânicas da doença, na medida em que provocam alterações na vida do doente e em sua identidade social.

O modo como é vivenciada a experiência de saúde/doença é mais uma manifestação da noção de valor do indivíduo em seu contexto. Toda a experiência humana, intelectual ou pratica, pressupõe uma distribuição diferencial - culturalmente definida - do valor no mundo, que permite, justamente, a orientação do sujeito em situação (Duarte, 2003).

Para compreender realmente como os saberes, representações e discursos fazem sentido para a ação, será conveniente sempre reportá-lo às necessidades cotidianas da vida das pessoas de um lado, e de outro, às 
características de suas relações sociais. Os elementos sociais, como os sistemas de valor e as referencias culturais, tem uma função. Cuidar da saúde e da alimentação, por exemplo, depende em grande parte, de diversos recursos e limitações relacionados ao trabalho, a renda ou a vida familiar. Parar de beber ou de fumar, por exemplo, pode ser uma decisão individual, baseada em alguma informação ou norma, mas é preciso, para se apreciar a dificuldade envolvida, compreender suas implicações relacionais estabelecidas pela cultura do grupo de pertença do individuo (Adam e Herzlich, 2001).

Por outro lado, o racionalismo científico, ainda predominante no contexto da saúde, nos induz a pensar que viver em condições de precariedade e vulnerabilidade é viver numa condição de doença. Desconsideram-se, nessa perspectiva, os significados que os próprios atores sociais, mesmo que em condições desfavoráveis, atribuem ao seu cotidiano e, principalmente, ao seu viver saudável no cotidiano de sua realidade (Erdmann, 2009).

Sabe-se que há importantes diferenças dentro de uma população, o que faz com que uns experimentem uma melhor qualidade de vida, em contraste com outros que adoecem e morrem com mais freqüência, muitas vezes por enfermidades distintas. Estas diferenças entre os indivíduos não se devem apenas às suas características pessoais, inatas ou adquiridas, mas também, e primordialmente, ao modo como a sociedade se organiza e divide financeiramente suas classes. A situação social é o contexto determinante na expressão das características pessoais (Almeida, 1992).

Em sociedades de economia capitalista, os bens e serviços produzidos pelo conjunto da sociedade, incluindo a assistência à saúde, não são igualmente acessíveis a todos os indivíduos; antes dependem da sua inserção no processo social de produção, ou seja, da sua condição de classe. Em face desta situação, com freqüência assume-se que é a classe social do indivíduo aquela que, em última instância, irá determinar os limites mais prováveis dentro dos quais se situará seu estado de saúde (Monteiro, Freitas e Baratho, 1989).

Um vasto campo de representações de enfermidade se aplicam frente às diferentes sociedades; nas classes populares, o desejo por uma "saúdeequilibrio", comparado à realização pessoal e ao prazer, não é exprimida. A saúde é compreendida por eles como um instrumento, tendo na ausência da doença a aptidão para o trabalho, enquanto na realidade atual, para as classes 
médias, a saúde é anunciada como valor pessoal organizador do comportamento e como resultante coletiva das políticas públicas e de ação do Estado (Adam e Herzlich, 2001).

É possível observar que para o individuo - e isso quanto mais elevada for sua categoria social - a saúde inscreve-se na temática da liberdade de expressão e da realização pessoal. Numerosos estudos, entretanto, mostram que à medida que se desce a escala social, o discurso de valorização da saúde se rarefaz e fica mais desligado da realidade das situações e dos comportamentos (Adam e Herzlich, 2001).

Ao prestar atendimento psicológico a jovens de classe popular tornou-se evidente a forma como sua condição particular de vida repercute nas suas doenças e acidentes. São freqüentes os casos de acidentes por descuidos e por falta de precauções mínimas. São também comuns os casos de jovens que sofrem violência física e vitimas de abuso sexual. Um menino de doze anos, ao relatar seu acidente, no qual sofre uma fratura exposta do fêmur, após cair de uma altura de quinze metros, demonstra esta realidade:

"Eu tinha bebido e usado outras coisas, aí eu cheguei em casa e, não me lembro direito, mas acho que dormi na soleira da janela. Acordei quando bati nos fios do poste da minha rua e depois caí no chão. Nem notei que tinha quebrado a perna, mas quando tentei ficar em pé o osso cortou pela pele."

A relação entre a forma da organização social e o tipo e intensidade de doenças incidentes e prevalentes, tem sido constatada em inúmeras verificações. Ao estudar historicamente a incidência e mortalidade por cólera, por exemplo, Barros (1986) afirma que a transmissão direta de doentes para sadios era mais freqüente nas famílias de trabalhadores pobres, nas quais o tamanho da moradia, entre outras condições, implicava maior risco de transmissão. A constatação da distribuição socialmente desigual da morbi-mortalidade consolidou-se em análises que discriminaram padrões distintos de adoecer conforme a categoria social das pessoas: as doenças dos pobres e as doenças dos ricos. A autora defende ainda que a possibilidade de análise da distribuição da morbi-mortalidade, em relação às classes sociais e frações fica sujeita às dificuldades e controvérsias que cercam o próprio conceito de classe social. 
Guimarães (2011) aponta em seus estudos alguns fatores considerados determinantes do adoecimento, entre esses existe um destaque para a precariedade da situação de vida de certos grupos. A violência cotidiana, em suas diversas formas, foi considerada como um fator de adoecimento das pessoas. A luta pela sobrevivência, que impõe baixos salários e falta de emprego, a criminalidade, a dificuldade de acesso às escolas e aos serviços de saúde, as condições insalubres de moradia, o dilaceramento das relações familiares, a falta de tempo para cuidar de si, entre outras expressões de violência, geram estresse, revolta, raiva, depressão e diversos outros sintomas.

A relação direta existente entre pobreza e suas questões em saúde é reafirmada a partir do momento em que nas populações pobres, a dificuldade de sobrevivência diária impõe um ritmo de tal forma exigente que torna difícil a renovação das energias tanto físicas quanto psíquicas. A depressão leve, a baixa estima de si, mal-estar, que se expressam muitas vezes em dores generalizadas e insônia, encontram-se disseminadas pela comunidade. Esse sofrimento está relacionado a problemas, como a falta de perspectiva de vida e de lazer, que limita sonhos e projetos de vida, e pode ser percebido como uma questão em saúde (Guimarães, 2011).

"Para a classe popular, é muito freqüente a mortalidade ocasionada por questões externas, como acidentes ocasionados por armas de fogo, tanto de pessoas inocentes quanto das envolvidas com o tráfico de drogas. Para os membros desta classe, faz parte do cotidiano, variados tipos de violência que ocasionam risco de morte, como os espancamentos, mutilações, brigas e práticas indiscriminadas de aborto." (Guimarães, 2011, p. 297)

Gutierrez e Minayo (2011) complementam esta visão ao relatar pesquisas onde é elaborada a questão da saúde por meio da apresentação de aspectos socioeconômicos. É abordada a influência da classe social, comparando dois grupos de diferentes condições sociais e econômicas e estruturas familiares. A partir deste recorte, são discutidos aspectos culturais da noção de causalidade das doenças, indicando que os mais pobres a atribuem a fatores ambientais, enquanto os de classe média tendem a interpretar a ocorrência de doenças em função de fatores psicológicos. Para as autoras, a etiologia das doenças concebida pelas classes populares é complexa e coerente. Guimarães (2011) entende que a classe popular se destaca das outras ao expressar uma visão ampla e integral de saúde, próxima da "tradicional', na medida em que não separam o corpo da alma, o homem da natureza, entre outras concepções. 
Também é possível observar que, em relação ao manejo das doenças, as classes populares utilizam as prescrições médicas de modo adaptado, mesclando-o com o conhecimento popular, enquanto a classe média tende a assumir a proposta da medicina biomédica, seguindo as prescrições médicas com maior rigor. Oliveira e Bastos (2000 apud Gutierrez e Minayo, 2011) encontraram ainda que o uso dos serviços também se mostra de modo diferencial. A mãe de classe inferior busca utilizar o sistema de saúde apenas para os filhos, cuidando de si com a automedicação, enquanto a mãe de classe média usa o sistema para os filhos e para si. Para cuidar dos filhos, a mãe de classe popular recorre ao sistema para curar, enquanto a mãe de classe média o utiliza de modo preventivo. 


\section{Classe popular, Saúde e o Cuidado Infantil}

Padrões culturais definem não somente o que é saúde, mas também o que é cuidado adequado à saúde, formatando sentidos e condutas. Para que se entenda o modo como os grupos e pessoas reagem e se organizam diante do fenômeno complexo que é a saúde/doença/cuidado é fundamental conhecer as representações, valores e lógicas presentes nas práticas cotidianas, construídas pelas e nas interações sociais. O cuidado à saúde, como prática social, se insere neste conjunto de elementos, uma vez que através dele se dá corpo as representações que atuam na construção do sujeito (Gutierrez e Minayo, 2011).

De acordo com Ayres (2004), não seria possível desconsiderar um aspecto importante quando se trata de pensar na questão do cuidado; trata-se da aplicação deste conceito à dimensão social dos processos de adoecimento e da construção de respostas a tais processos. Quase sempre que se fala em cuidado, humanização ou integralidade, é feita referência a um conjunto de princípios e estratégias que norteiam a relação entre o paciente e o cuidador.

A própria construção das identidades pessoais que fundamentam os projetos individuais que perpassam a idéia do cuidar, se faz na interação com o outro, nas inúmeras relações nas quais qualquer indivíduo está imerso, já antes mesmo de nascer. Os horizontes de normas não são os únicos a orientar os conceitos de saúde, doença e cuidado, mas os obstáculos à felicidade que estes horizontes permitem identificar são também fruto da vida em comum. A idéia de valor da vida só se concebe e faz sentido no plano do convívio com o outro, no interesse em tornar compatíveis finalidades e meios de uma vida que só se pode viver em comum (op. cit.).

Sentidos culturais, coletivos e pessoais interagem para resultar em uma determinada forma de cuidar de si e de outros. As famílias e as pessoas com as quais se relacionam constroem e negociam significados para a provisão de cuidados. Essas relações entre aspectos culturais e coletivos são dialéticas, uma vez que famílias atuam como reprodutoras da ordem social e, ao mesmo tempo, nelas emergem aspectos individuais e relacionais inovadores, integrando a 
atuação criativa do indivíduo e sua forma de traduzir o que percebe do meio (Gutierrez e Minayo, 2011).

O nível de conhecimento sobre os processos evolutivos do homem e sobre os mecanismos das doenças, da mesma forma, deve ser considerado dentro do quadro de referência dado pela classe social. O cuidado, em suas diversas formas, varia dentro das diferentes modos de vida, renda e escolaridade (Gutierrez e Minayo, 2011).

Kobarg e Vieira (2008) propõem o nível de escolaridade como ferramenta para compreensão das diferenças nas crenças sobre cuidados parentais e 0 desenvolvimento infantil. O grau de conhecimento dos pais afetará as práticas de cuidado e vice-versa, e, assim como as práticas e crenças, transformarão e serão transformadas pelo ambiente físico e social.

A série de idéias que pais e mães têm sobre crianças e famílias, e as concepções a respeito do modo como os filhos deveriam ser criados são representadas por modelos culturais também conhecidos como teorias parentais. O estudo destes modelos pode contribuir para a compreensão de como é estabelecida a vida diária das crianças e como se expressa em hábitos de cuidado rotineiros e que devem ser considerados em função do ambiente em que a criança vive. Assim, o contexto pode ser pensado, também, como forte influencia na forma como o cuidado parental será exercido (op. cit.).

A partir dos aspectos discutidos, afirma-se que, para que haja uma verdadeira compreensão da vivência do momento de enfermidade infantil, da mãe-cuidadora e da relação mãe-filho no momento de doença, torna-se necessário levar em conta o seu contexto, classe social e, consequentemente, sua realidade e seus valores (Velho, 1987).

\section{1.}

\section{Investimento Infantil}

Em princípio, a espécie humana caracteriza-se pelo alto investimento na criança (Lordelo, 2006). Supõe-se que os sistemas de cuidado a que o indivíduo 
é exposto, principalmente durante os primeiros anos de vida, têm conseqüências importantes nos resultados desenvolvimentais (Keller, 1998 apud Lordelo, 2006).

$\mathrm{Na}$ primeira fase do desenvolvimento humano é adquirida uma matriz social primária, adaptativa em relação ao ambiente no qual o indivíduo se desenvolve. Esta matriz social, construída nas interações com os cuidadores, resultado do investimento à criança, tem como função capacitar o indivíduo a adotar estratégias de acordo com os desafios do ambiente em que está inserido (Keller, 1998 apud Lordelo, 2006).

No entanto, as diferenças entre as pessoas e os contextos sociais permitem caracterizar dois distintos padrões de trajetórias desenvolvimentais: 0 primeiro estilo caracteriza aquele que, na infância, experimenta um ambiente de escassez de recursos, com baixo investimento parental e clima familiar insatisfatório; o segundo descreve o indivíduo que, vivendo uma situação de abundância de recursos, experimenta um alto investimento parental e um clima familiar positivo (Lordelo, 2006).

Além de conseqüências psicológicas nas relações de apego entre criança e pais, os dois tipos de experiências levam a diferenças no início da puberdade, com o primeiro amadurecendo mais cedo que o segundo. Essas trajetórias continuam a se diferenciar nos estilos reprodutivos subseqüentes, sendo o primeiro mais quantitativo, significando assim, mais filhos, menor espaçamento entre os nascimentos e baixo investimento parental; ao contrário, o segundo seria mais qualitativo, implicando menos filhos, maior espaçamento entre os filhos e alto investimento parental (op. cit.).

Partindo deste pressuposto, pode-se considerar também que a mortalidade infantil representa um importante indicador para compreensão da cultura e do desenvolvimento de uma sociedade. Desde a metade do século $X X$, observa-se que tal índice deixa de ser considerado como problema exclusivo da Higiene, para se tornar foco da economia e da sociologia (Almeida, 2002).

Seguindo esta abordagem, Almeida (1992) destaca um estudo que fornece questões relevantes na determinação de todas as categorias da mortalidade infantil, desde o início da gestação até o final do primeiro ano de vida. O estudo demonstrou a relação entre a doença e a morte enfatizando variáveis como renda familiar, alimentação, saneamento, educação e atenção 
médica. As condições biológicas da mãe, relacionada a condições sócioeconômicas desfavoráveis, promovem maiores incidências de perdas fetais, além de outras categorias da mortalidade infantil. Evidencia-se, também, que estes fatores estão estreitamente relacionados entre si, e a distribuição nãoigualitária de todos esses componentes de vida é apenas expressão da sua organização social, econômica e política.

Barber (2003 apud Lordelo, 2006), por sua vez, investigou a hipótese de que o número de nascimentos de genitores solteiros aumentaria seguindo a diminuição de expectativas de investimento parental, medida por altas taxas de desemprego de homens adultos, baixa renda e altas taxas de gravidez na adolescência. Os resultados mostraram que a taxa de nascimentos de mães solteiras declina seguindo o aumento de expectativas de investimento paternal e aumenta conforme a elevação de escolaridade da mulher.

Esta teoria tem o potencial de integrar dimensões biológicas e culturais a uma psicologia do desenvolvimento humano. Compreende-se que o modo como o indivíduo é criado influencia as adaptações do organismo adulto. No entanto, enquanto cultura e variáveis pessoais sejam vistas como determinantes da personalidade, elas não podem ser arbitrárias e devem estar relacionadas com estratégias de adaptação (Lordelo, 2006).

Uma vez que variáveis como renda e escolaridade dos pais estão fortemente associadas a resultados no desenvolvimento em muitas esferas, é evidente que as famílias compostas pelos dois genitores têm, em geral, mais recursos materiais do que aquelas formadas por apenas um dos genitores. Isso torna difícil separar dimensões materiais e psicológicas do ambiente familiar e seu efeito no desenvolvimento da criança (op. cit.).

\section{2.}

\section{A Família e o Cuidar}

Gutierrez e Minayo (2011) destacam a família como a principal microestrutura para compreensão de representações e práticas relativas ao processo de saúde /doença /cuidado. A família é uma unidade de 'cuidado de 
saúde popular'. Tem seu próprio ponto de vista sobre o processo saúde/doença, sobre suas próprias atitudes e sobre o modo de cuidar.

Erdmann (2009) revela que o entendimento do mundo imaginário do ser 'família saudável' no quotidiano em tempos pós-modernos exige uma imagem de ser 'família saudável' que elas próprias constroem ao longo de todas as interações do seu processo de viver, isto é, por meio de seus significados, crenças, valores, símbolos, situações existenciais, laços de afeto, entre outros.

Helman (1994 apud Leite e Vasconcellos, 2006) descreve a família como a primeira arena de assistência informal. Entre 70 e 90 por cento dos tratamentos de saúde ocorrem dentro da família. Para Loyola (1982 apud Leite e Vasconcellos, 2006), nas classes populares, primeiramente esgotam-se as possibilidades de recursos terapêuticos familiares, advindos de experiências acumuladas que permitem medir sua eficácia, para que, apenas então, se recorra a uma orientação médica.

Menéndez (1992 apud Leite e Vasconcellos, 2006) também descreve a família como primeira instância de cuidados de saúde, acrescentando que ela, ou o grupo doméstico, constitui a unidade onde se constroem e operam os principais determinantes da morbidade e mortalidade nos diferentes grupos etários, particularmente dos menores de cinco anos, tanto positiva quanto negativamente. É também a instituição sobre a qual repercutem as consequências das crises econômicas. Para o autor, não cabe dúvida de que a família, ou grupo doméstico, é uma das unidades de descrição e análise do processo saúde/doença/atenção mais estratégicas, pelo papel central que ela desempenha em tal processo.

O sujeito, ao pensar um padecimento ou uma enfermidade, ao decidir o que fazer com ela, não atua isoladamente e sim como parte de uma micro/macro estrutura. A família constitui a micro estrutura que teria mais peso na constituição das representações e práticas dos sujeitos em relação ao processo saúde/doença/atenção (Leite e Vasconcellos, 2006).

A família 'ampliada', ou a rede de relações sociais mediada por ela ou pelos próprios indivíduos, tem sido tomada por diversos autores como objeto de estudo mais apropriado para a compreensão das formas de lidar com a doença e as escolhas terapêuticas (op. cit.). Compreende-se que a família, quando cuida, 
não o faz sozinha, mas amparada por uma rede de relações sociais espontâneas e mobilizadoras de recursos que estão além das circunstâncias imediatas e servem de apoio em momentos de necessidade e de crise. A rede é considerada, portanto, como um valioso recurso e como a principal fonte de ajuda, principalmente pela família de baixa renda (Gutierrez e Minayo, 2011).

As redes constituem o contexto social em que o apoio fornecido é mútuo em situações em que os necessitados alternam favores e ajudas e verdadeiras redes de reciprocidade. Quando essa rede de relações está extremamente restrita, ou é inexistente, as consequências são bastante graves, especialmente em grupos de classe popular, em que os outros recursos são exíguos (op. cit.).

A família, unidade fundamental para o cuidado à saúde, muitas vezes é representada em sua cultura, seus hábitos e modo de vida pela condução da mulher-mãe; categoria decisiva para as ações de saúde no lar (Caponi, 2000 apud Leite e Vasconcellos, 2006)

Na prática cotidiana, as mães e suas famílias utilizam-se das informações dos setores biomédicos e populares para a constituição de sua estrutura de apoio na sobrevivência do grupo. A família e a mãe podem ser consideradas, então, como 'recursos' para o setor da saúde, como sugere Menéndez (1992 apud Leite e Vasconcellos, 2006), pois são utilizadas para aplicar programas de educação em saúde, de planejamento familiar, de higiene e tantos outros.

\section{3.}

\section{A Mulher/Mãe e o Cuidar}

Muitos autores apontam a mulher como figura que, na história e na cultura, no Brasil e no mundo, tem incorporado funções de cuidado. Na maioria dos estudos, o pressuposto do cuidado feminino é tomado como um dado sem preocupação com maiores questionamentos e discussão das implicações desta relação (Gutierrez e Minayo, 2011).

A capacidade de cuidar da saúde dos filhos pequenos é, no entanto, variável e mediada por fatores sociais permeados pelas condições de vida. Carvalhães e Benício (2002 apud Gutierrez e Minayo, 2011) discutem os 
aspectos sociais associados a outros elementos, apontando os seguintes fatores de risco à desnutrição infantil: estrutura familiar com a falta do companheiro, internação materna durante a gravidez, precária saúde mental materna, estresse familiar, baixa escolaridade materna, mães desempregadas e a idade da criança quando do retorno da mãe ao trabalho. Evidencia-se, assim, a relação direta entre saúde da criança e o cuidado materno.

Siqueira, Sigaud e Rezende (2002) cogitam a "simples" presença da mãe como estímulo para as respostas do filho; sua mínima atenção, mesmo quando não está diretamente relacionada a ele, seria significativa. Durante o primeiro ano de vida, experiências e ações intencionais constituiriam a mais decisiva influência no desenvolvimento de vários setores da personalidade da criança; bastaria a presença da mãe para suscitarem-se reações.

Outros estudos realizados sobre a relação mãe e filho concluem que é essencial para a saúde mental das crianças pequenas um relacionamento íntimo, carinhoso e contínuo com sua mãe ou alguém que realize a função materna, através do qual ambos sintam satisfação e prazer. (op. cit.).

Assim, nas enfermidades infantis, torna-se clara a relevância do papel da mãe ou de alguém que realize sua função, sendo a sua participação um fator decisivo sobre os cuidados de saúde. A partir dos fatores descritos, é evidente a centralidade do papel materno os prejuízos que a ausência desta mãe pode provocar (op. cit).

O prejuízo decorrente da falta de uma pessoa realizando a função de materna pode ser vista, também, na fala de um jovem de doze anos, criado por uma irmã pouco mais velha, ao ser questionado sobre sua falha em atender as recomendações médicas depois de receber alta:

"Não fiz o que o médico disse, não tomei os remédios. No primeiro dia eu já fui pra rua, bebi e usei drogas. Acho que foi por isso que tive a complicação e voltei para o hospital (...). Não me preocupo se vou ficar bom, não penso no futuro, não quero viver muito mesmo. Quero mais é curtir tudo, se não for para curtir é melhor morrer."

Percebeu-se, neste mesmo jovem, a enorme falta de investimento materno e familiar, quando, ao receber atendimento psicológico, dizia: "Acho 
estranho alguém olhando para mim e conversando comigo. Não to acostumado a falar de mim. Dá muito nervoso."

É possível observar, na internação pediátrica, que a criança desacompanhada apresenta maiores dificuldades em sua recuperação, podendo até mesmo sofrer preconceito pela equipe do hospital. O paciente nesta condição é descrito como "problemático", "mal educado" e "desobediente". Em determinados casos, as acompanhantes de outras crianças se sensibilizam: "Tento ajudar, chamo a enfermeira quando vejo que ele está sentindo dor. Ele está sozinho todo esse tempo, não teve nem visita da família. Já percebi que quando é assim a enfermagem relaxa e o coitadinho fica aqui largado."

Boltanski (1989 apud Leite e Vasconcellos, 2006), ao buscar compreender o processo pelo que passa a mãe diante da enfermidade do filho, revela que a maioria das doenças infantis são vistas como 'normais da idade' e tratadas em casa por ela. Apenas quando 'mal curadas' ou quando o conjunto dos sintomas se aproxima do que as mães consideram grave, que é buscado o médico.

Observa-se fazer parte do papel da mãe a realização de duas operações mentais fundamentais quando a saúde ou bem estar da criança está ameaçada: relacionam os sintomas percebidos com o rol de doenças conhecidas e, então, relacionam a doença com o rol de remédios indicados para curar a referida doença. A partir de tais operações mentais é determinado pela mãe a gravidade e risco que uma situação representa e que atitudes devem ser tomadas para a resolução do problema (Boltanski, 1989 apud Leite e Vasconcellos, 2006).

Para Oliveira e Angelo (2000), a mãe, ao acompanhar um filho hospitalizado, é exposta a uma vastidão de eventos que promovem diversos sentimentos. Suas manifestações, representações e causas variam de acordo com seu contexto e realidade. Vasconcelos, Leite e Scochi (2006), por outro lado, defendem que o impacto da experiência entre mães acompanhantes no contexto de uma unidade de internação pediátrica revela uma reviravolta na vida familiar, obrigando a mãe a modificar seus hábitos e sua relação com os familiares. Enfatizam que, em função do curso de sua vida mudar quando o filho necessita ser internado, essa mãe tem que se afastar das atividades do dia-adia, da família, dos amigos, da casa e do trabalho. 
A hospitalização da criança provoca na mãe sentimentos ambíguos: ela, ao mesmo tempo em que sente a necessidade de acompanhar seu filho doente, ressente-se de não poder dar assistência aos outros filhos que ficaram em casa. Este é outro fator que causa cansaço na mãe, pois se sente cobrada pelos afazeres domésticos e ao mesmo tempo impossibilitada de fazê-los. (Siqueira, Sigaud e Rezende, 2002)

Diante desta realidade e do modo como a classe popular investe na vida de suas crianças, é possível compreender o discurso de muitas mães da classe popular, acompanhantes na pediatria do hospital. Tem-se como exemplo a fala de uma mãe, acompanhante da filha de quatro anos, internado em decorrência da contaminação pelo vírus H1N1, decidida a abandoná-la:

"Não vou poder ficar mais tempo aqui, tenho um filho de um ano e uma filha de treze e não é justo ficar mais tempo me dedicando só para essa só porque ela esta doente(...)Ela já está aqui há duas semanas e não melhora, estou achando que não vai vingar mesmo."

\section{4 .}

\section{A Mãe de Classe Popular e a Gravidez na Adolescência}

Embora exista uma ampla bibliografia no que se refere à relação mãefilho, assim como muitos trabalhos que se dedicam à compreensão da criança enferma - na forma como esse evento afeta seu crescimento e desenvolvimento emocional - e da mãe cuidadora, pouco se dedica à análise desses aspectos diante do contexto da classe popular (Oliveira e Angelo, 2000). Para que se compreenda a relação materno-infantil dentro deste contexto é fundamental abordar a gravidez na adolescência, fenômeno vivenciado por muitos dos jovens das classes subalternas.

A adolescência é determinada pela Organização Mundial de Saúde (OMS) dentro de uma faixa etária que vai dos 10 aos 19 anos e, pelo Estatuto da Criança e do Adolescente (ECA), dos 12 aos 18 anos, porém esta demarcação por faixa etária não abarca o entendimento da adolescência como um processo social.

Durante sua trajetória, o adolescente passa por mudanças e enfrentamentos sociais, os quais poderão repercutir de forma mais ou menos intensa em sua vida, dependendo do contexto em que está inserido. Ressel 
(2009) ressalta que é preciso considerar as condições econômicas e culturais que determinam comportamentos individuais e grupais dos adolescentes. O autor entende, neste viés, a adolescência como um fenômeno único e diverso, circunscrito cultural e historicamente.

Dias e Teixeira (2010) compartilham deste pensamento afirmando ser a adolescência, antes de tudo, um evento social. Adolescência é um termo utilizado para tratar de um período do desenvolvimento no qual certas expectativas sociais recaem sobre os indivíduos e configuram um modo de ser adolescente fruto da conjugação de transformações biológicas, cognitivas e emocionais pelas quais as pessoas passam.

A transição da infância para a vida adulta é, para o sujeito, uma fase de descobertas e de novas experiências. Todo o desenvolvimento corporal aliado ao afloramento da sexualidade faz com que esta seja uma fase da vida que mereça atenção especial, pois é nesta época que o individuo questiona, descobre e afirma sua personalidade perante a sociedade. Ressel (2009) atenta ao fato de na maioria dos casos, a adolescência configurar um momento em que o sujeito encontra-se vulnerável e exposto a muitos riscos decorrentes das transformações que passa. Tal vulnerabilidade ocorre diante do reconhecimento das possibilidades de poder e autocontrole pelo adolescente sobre sua vida. O risco é agravado quando, naturalmente, nesta fase, ocorre o afastamento da família e a identificação a grupos de sua semelhança.

Nesta linha de pensamento, podemos observar a acentuação ainda maior desse risco no que se refere à mulher no processo de adolescer. Percebe-se que as adolescentes vivenciam uma construção do "ser mulher", a qual passa por um processo específico, que se efetiva por meio da socialização de cada indivíduo. Este fato as torna vulneráveis ao seu meio social e cultural à medida que as expõe a diversos fatores, dentre eles, a gravidez precoce (op. cit.).

A gravidez na adolescência é tema abordado como problema de saúde pública e é compreendida como empecilho para a adolescente cumprir suas funções sociais. De acordo com sua pesquisa, Santos e Schor (2003) estimam que cerca de $21,7 \%$ da população brasileira tenha entre 10 e 19 anos de idade: $11,1 \%$ entre 10 e 14 anos e 10,6\% entre 15 e 19 anos. As estatísticas também revelaram que o número absoluto e relativo de gestações em adolescentes vinha aumentando, especialmente no grupo de 10 a 14 anos. 
O conhecimento que se tem sobre a gravidez na adolescência se baseia nos resultados de pesquisas que associam o fato a: assistência pré-natal deficiente; maior incidência de patologias durante e após a gestação; maior risco de mortalidade e maior risco psicossocial (Santos e Schor, 2003).

É possível observar a presença marcante de alguns fatores no perfil das adolescentes com repetição da gravidez, demonstrando a existência de uma influência causal multifatorial por trás do evento. Estes dados apontam para a menarca precoce (até os 12 anos), primeira relação sexual após curto intervalo da menarca, repetência escolar, abandono escolar, ausência de ocupação remunerada, baixa renda familiar, histórico familiar de gravidez na adolescência e ausência do pai por morte ou abandono (Persona, Shimo e Tarallo, 2004).

São levados em conta ainda, como possíveis fatores facilitadores da gravidez não planejada na adolescência, o desconhecimento ou uso inadequado dos métodos contraceptivos, ignorância da fisiologia da reprodução e das conseqüências das relações sexuais, utilização de métodos de baixa eficiência e diminuição da capacidade de julgamento devido ao efeito de bebidas alcoólicas e drogas (op. cit.).

A partir dos dados apontados, questiona-se também se as características e consequências negativas associadas à gravidez/maternidade na adolescência são devidas à idade da gestante ou se ao contexto social desfavorável em que vivia antes mesmo de ficar grávida. Santos e Schor (2003), entre outros autores, compreendem que a gravidez na adolescência é geralmente não desejada, não planejada, produto da falta de informação e de um contexto de desvantagem socioeconômica.

O significado da gravidez e da maternidade pode não ser único ou definitivo e tem aspectos positivos e negativos para a adolescente. Embora 0 desejo consciente ou inconsciente de engravidar seja um dos fatores que leva à gravidez na adolescência, ele pode estar sendo influenciado por fatores internos e externos. Um deles é o tipo de relacionamento familiar, especialmente entre pais e filhos, que propicia determinados comportamentos (Persona, Shimo e Tarallo, 2004; Santos e Schor, 2003). 
Persona, Shimo e Tarallo (2004) revelam que mais da metade das adolescentes engravida por outras causas que não o desejo pela maternidade em si. São observados muitos casos de adolescentes que engravidaram com o objetivo de prolongar um relacionamento amoroso, sair da casa dos pais e evitar o clima familiar desagradável. Afirmar sua feminilidade através da fertilidade, encontrar nos cuidados com o filho um objetivo para sua vida e sanar a solidão na companhia do filho também se apresentam como fatores que influenciam este comportamento.

$\mathrm{Na}$ internação pediátrica, observa-se a presença de muitas mães adolescentes (na posição de acompanhantes) em sua maioria sem preparo, insatisfeitas e incapazes de elaborar a situação em que se encontram. Ao revelarem o motivo pelo qual engravidaram, nota-se que muitas o fizeram intencionalmente, porém, sem compreender de fato no que acarretaria a chegada de um filho. O discurso de uma mãe de treze anos, ao vivenciar as conseqüências de suas escolhas é revelador:

"Engravidei do meu namorado para ver se a gente ficava junto. Amo muito o pai do meu filho até hoje, mas quando eu dei a noticia de que estava grávida, ele terminou o namoro. Até hoje eu sofro muito, queria que ele voltasse. Quando eu tava grávida ele passava na minha frente com outras namoradas e nem falava comigo. Hoje, ainda por cima tenho que cuidar sozinha do meu bebê. Tenho pena dele, o pai não procura, só viu poucas vezes."

A partir dos aspectos descritos, compreende-se que muitas adolescentes buscam com a gravidez o preenchimento de um vazio interior decorrente da imaturidade emocional e da falta de perspectiva no contexto em que vivem. Assim, como conseqüência e agravante da situação, é possível observar que grupos de adolescentes de classes populares apresentem ainda uma segunda, terceira ou até quarta gestação durante a adolescência, em sua maioria sem planejamento (Persona, Shimo e Tarallo, 2004).

Reis e Oliveira-Monteiro (2007 apud Dias e Teixeira, 2010) também observaram que a falta de oportunidades de vida e as carências materiais e emocionais se encontram associadas à maternidade na adolescência e ao desejo de ter um filho. Em um estudo com jovens participantes de um programa 
de inclusão sócio-cultural, com moradores de uma favela na grande São Paulo, os autores encontraram que, entre as meninas estudadas, "sentir-se só" (24\%), "brigas ou tristezas com a família" (23\%), "falta de opções na vida" (13\%) e "gostar de crianças" (10\%) foram as principais razões indicadas para o desenvolvimento de uma gravidez na adolescência.

Esta pesquisa corrobora o fato da gravidez neste período representar, muitas vezes, a busca por reconhecimento e concretização de um projeto de vida para algumas adolescentes, especialmente aquelas de nível socioeconômico menos favorecido. Nesse sentido, conclui-se que a maternidade na adolescência foi compreendida por alguns jovens como uma alternativa viável para lidar com uma série de problemas e situações desfavoráveis presentes em seu contexto sócio-afetivo. A carência afetiva associada à ausência ou limitação nas perspectivas de construção de um projeto de vida são fatores que contribuem para a ocorrência de uma gestação na adolescência em classes desprivilegiadas (Dias e Teixeira, 2010).

"A gestação na adolescência se apresenta como um projeto de vida valorizado em um contexto em que não existem muitas alternativas possíveis de implementação de outros projetos de vida. Alguns estudos demonstram que a maternidade, para uma grande parcela das jovens, é desejada e se configura como um dos únicos projetos possíveis de reconhecimento social. Além de representar, em alguns casos, um modo de conceber a concretização da identidade feminina." (Dias e Teixeira, 2010, p. 127)

Rangel e Queiroz (2008 apud Dias e Teixeira, 2010), ao compararem as representações sociais de adolescentes de diferentes estratos econômicos sobre a gravidez nesse período do desenvolvimento, encontraram entre meninas de um nível econômico menos favorecido que ter um filho era uma bênção divina, algo "natural" da identidade feminina. Em suas representações, a maternidade estava vinculada ao "poder de ser mulher" e à construção da própria família. As autoras observaram que a representação da gravidez na adolescência esteve atrelada à necessidade de valorização e de um reconhecimento social, o que não ocorria com adolescentes dos estratos mais favorecidos. Entre essas jovens a gestação nesse momento de vida representava, além de um comprometimento dos planos futuros, uma sobrecarga financeira e uma experiência não normativa no desenvolvimento humano. 
Kassar (2006) afirma que, apesar da gravidez na adolescência ser freqüente em todos os níveis sociais, a maior incidência ocorre nas populações de baixa renda. Mães adolescentes pobres residem em piores condições, têm menor renda per capita e escolaridade em comparação com as mães mais velhas da mesma classe social. Por isso, expõem seus filhos a um maior risco de doença e morte. Esse grupo entra para a vida adulta muito mais precoce e abruptamente do que uma jovem de classe privilegiada, que pode prolongar sua adolescência. O problema, então, é que a condição de pobreza parece contribuir para uma maior incidência de reprodução na adolescência, o que, por sua vez, cria uma probabilidade ainda maior de que essas jovens permaneçam vivendo em condições de miséria.

A idéia de que gravidez na adolescência é uma porta para o ciclo da pobreza é afirmada por Kassar (2006) em um estudo que objetivava comparar características socioeconômicas de mães de 20 a 34 anos, categorizadas de acordo com a experiência de gravidez na adolescência. Foram encontradas as piores condições sociais naquelas que tinham engravidado durante este período.

"Em termos sociais, a gravidez na adolescência pode estar associada com pobreza, evasão escolar, desemprego, ingresso precoce em um mercado de trabalho não-qualificado, separação conjugal, situações de violência e negligência, diminuição das oportunidades de mobilidade social, além de maus tratos." (Dias e Teixeira, 2010, p. 125)

A ocorrência de problemas de saúde tanto na jovem como na criança pode estar mais relacionada ao estado de pobreza do que à idade da jovem propriamente. Uma boa parcela da população de gestantes adolescentes encontra-se em condições sócio-econômicas precárias, o que por sua vez está associado a uma maior ausência de condições adequadas de higiene, habitação, alimentação e saúde (Dias e Teixeira, 2010). A fala de uma mãe adolescente corrobora esta percepção:

"Eu tinha uma irmã um ano mais velha que morreu no ano passado aqui nesse hospital. Ela também estava grávida e teve algumas complicações no oitavo mês. Ela faleceu ainda na emergência por causa de complicações com o uso de cocaína. O filho dela quase não sobreviveu e hoje é criado pela minha família." 
O fenômeno da gravidez precoce torna-se ainda mais complexo quando é exigido que a jovem mãe redefina sua identidade levando em consideração o fato de que sua vida, da gravidez em diante, estará vinculada às demandas do filho. A projeção de si mesmo no futuro, elemento importante da construção da identidade na adolescência é substancialmente afetada no caso das adolescentes que engravidam, que precisam lidar com uma nova perspectiva temporal dada pelo desenrolar da gravidez e do próprio desenvolvimento do bebê após o nascimento. Planos são deixados de lado ou redimensionados em função da gestação e da maternidade (Dias e Teixeira, 2010).

Adaptar-se ao papel materno, ao mesmo tempo em que se encontra na posição de adolescente e filha, não é uma tarefa fácil. De fato, as transformações emocionais e cognitivas, pelas quais as adolescentes passam nesse período do desenvolvimento, fazem com que as jovens apresentem mais dificuldades para desempenhar de maneira satisfatória o papel materno, uma vez que não dispõem, na maior parte das vezes, dos recursos psicológicos necessários para entender e tolerar as demandas diárias e frustrações da maternidade. As dificuldades, inseguranças e falta de habilidades para o exercício do papel materno, associadas ao pouco conhecimento sobre desenvolvimento infantil que as adolescentes possuem, podem se configurar em um quadro de risco para o desenvolvimento do bebê, uma vez que as respostas das jovens mães às demandas de seus filhos tende a ser aquém das suas necessidades (Dias e Teixeira, 2010). Tais questões estão presentes no discurso de uma adolescente de quatorze anos, acompanhante do seu filho de um ano:

"A enfermeira brigou comigo quando ele sujou a cama e eu bati nele, mas é que não agüento mais ficar presa nesse hospital (...). Fico triste e culpada quando vejo que não sou uma boa mãe, como algumas (mais velhas) aqui da enfermaria. Eu amo o meu filho, mas não da maneira como uma mãe deveria amar um filho. As vezes penso que preferia que ele não existisse, mas sei que tá errado e fico muito culpada. (...) sei também que ninguém vai dar emprego pra uma menina com filho."

Conclui-se, então, que a gravidez na adolescência representa um sério e complexo problema de saúde pública. Se, por um lado, a gravidez indesejada coloca em risco a vida de algumas adolescentes ao, por exemplo, provocarem o aborto, por outro, quando desejada, pode representar a concretização de um 
projeto de vida ou a necessidade de compensar certas insatisfações, dada a crise econômica e a consequente falta de oportunidades profissionais que impossibilitam outras formas de realização. Ao mesmo tempo, assumir a maternidade representa, para essas adolescentes, um exercício efetivo de controle sobre seu corpo, sua fertilidade e seu poder de "ser mulher". Pode ainda representar a construção de sua própria família, principalmente se essa jovem vem de uma família desestruturada. De todo modo, a maternidade precoce continua sendo um impedimento para a melhoria da condição educativa da mulher em todas as partes do mundo, e contribui para reduzir a qualidade de vida da mulher e de seus filhos (Guimarães, 2011). 


\section{Conclusão}

A partir do presente trabalho é possível observar que são diversas as formas de existir em sociedade, assim como são múltiplas as maneiras de se organizar enquanto família e, conseqüentemente, estabelecer uma relação materno-infantil.

Para entender uma cultura ou classe social é fundamental a contextualização dos conceitos para que ocorra uma compreensão justa e fiel da realidade. A aplicação de códigos de uma sociedade para a análise de outra acarreta distanciamento, uso de preconceitos e distorções desta realidade.

A saúde e sua representação dentro de cada grupo social espelham o investimento que se tem na vida de seus membros, fazendo dela uma útil ferramenta para a compreensão de suas regras e valores.

A condição social exerce forte influência sobre o desenvolvimento infantil, sendo a infância um "termômetro" para que se evidencie o momento e circunstancia em que se encontra uma cultura. Deste modo, a partir do estudo das representações de saúde dentro da classe popular é possível um mais profundo entendimento do lugar ocupado pela criança e o cuidado a ela dedicado.

Observa-se que os membros de cada classe investem em si, seus filhos e em todas suas relações de modo proporcional a como neles foi investido originalmente. Em uma família de classe abastada, a chegada de um novo membro é uma situação de grande investimento financeiro e afetivo que se propagam ao longo de sua vida, com a criança de classe popular o mesmo não ocorre.

A distinção entre a posição ocupada pelo jovem de classe popular e o jovem de outras classes é ampla. Suas mães, muitas vezes ainda adolescentes, geram filhos sem investimento ou planejamento na procura de, através deles, dar um sentido às suas próprias vidas. A gravidez como projeto de vida, decorrente da restrita possibilidade de desenvolver outros projetos, apenas restringe ainda mais as chances de ascensão social. Em muitos casos, o despreparo psíquico e emocional da mãe gera ainda prejuízos à saúde e ao desenvolvimento do bebê. 
Desta forma, são colocadas no mundo crianças com pouco espaço para "serem crianças", como é defendido no modelo de família moderna, sem acesso a atividades "próprias da infância", como estudo e lazer. Muitas acabam por repetir o padrão de seus pais: não elaboram um projeto de vida, engravidam precocemente e falham em alcançar melhores condições de vida.

Ter uma infância adequada e levar uma vida saudável são construções a partir das condições em que se vive e das interações com o meio. Compreender o ser e o viver no mundo implica em compreender o ser dentro do significado que cada indivíduo, na sua singularidade, atribui às suas vivências, comportamentos e interações.

O ser humano é objeto da cultura em todos seus aspectos, incluindo o momento de adoecimento e busca por tratamento. A idéia de ser saudável depende, então, dos diferentes movimentos que integram o processo de viver a saúde e a doença.

Para que se desenvolva um viver mais saudável é preciso, portanto, conhecer e se apropriar dos significados vivenciados no quotidiano imaginário de cada indivíduo e grupo social. Incrementar práticas diferenciadas em saúde/cuidado implica em elaborar práticas importantes do ponto de vista do sujeito, substantivas cientificamente e viáveis economicamente.

Existe uma imensa parcela da população que não será integrada de forma satisfatória na economia moderna e para quem a distribuição de alguns benefícios pelos governos não irá gerar mudança de realidade. Tendo como base o presente trabalho, é possível propor que os programas públicos, dirigidos a promover a saúde e a cuidar dessas pessoas, entendam e trabalhem a premissa de que os homens não possuem apenas necessidades, mas também desejos e medos, e que o seu sofrimento precisa ser atendido. Deve-se cuidar para que, o agente da saúde, ao encontrar sistemas culturais diferentes do seu particular, aplique relativismo à sua noção de cuidado para que seja realizado um atendimento eficaz.

É ideal que programas dirigidos a adolescentes as ajudem a elaborar outras formas, diferentes da maternidade, de satisfazer suas necessidades emocionais. Isso seria possível a partir de atividades educativas voltadas para o 
desenvolvimento de habilidades e para a elaboração de projetos de vida. São, por outro lado, fundamentais os programas educativos sobre desenvolvimento sexual, objetivando a diminuição do risco de gravidez precoce.

Ao voltar o olhar para os aspectos relacionados à saúde dentro do universo da classe popular, não se deve esperar ou desejar que esta seja uma réplica - em códigos e regras - das classes abastadas, com seus modelos de família moderna. Deve-se apenas buscar que os membros das classes populares tenham acesso aos seus direitos básicos, que suas necessidades sejam atendidas e seu sofrimento seja ouvido. Para esses, espera-se que não persista a saúde precária e as altas taxas de mortalidade. Em suma, que existam condições mínimas para a criação de um espaço para um viver saudável, assim como possibilidades de elaboração de projetos de vida e realizações.

Idealiza-se que seus membros não sejam esquecidos ou marginalizados e que suas crianças não se sintam vivendo em condições de violência, miséria e abandono, sendo compreendidos e respeitados dentro de sua própria cultura e valores.

"Não se cuida efetivamente de indivíduos sem cuidar de populações, e não há verdadeira saúde pública que não passe por um atento cuidado de cada um de seus sujeitos." (Ayres, 2004, p. 28) 


\section{Referências Bibliográficas}

ADAM Philippe; HERZLICH Claudine. Sociologia da doença e da medicina. Bauru: EDUSC, 2001.

ALMEIDA, Luis Eduardo A. de et al . Peso ao Nascer, classe social e mortalidade infantil em Ribeirão Preto, São Paulo. Cad. Saúde Pública, Rio de Janeiro, v. $8, \quad$ n. 2, June 1992. Disponível em: <http://www.scielo.br/scielo.php?script=sci_arttext\&pid=S0102311X19920002000 11\&lng=en\&nrm=iso>. Acesso em 20 Abril 2011. doi: 10.1590/S0102$311 X 1992000200011$.

ARÈIS, Philippe. História Social da Criança e da Família. Rio de Janeiro: Ed. Zahar, 1978

AYRES, José Ricardo de Carvalho Mesquita. O cuidado, os modos de ser (do) humano e as práticas de saúde. Saude soc., São Paulo, v. 13, n. 3, Dec. 2004 . Disponível em: <http://www.scielo.br/scielo.php?script=sci_arttext\&pid=S0104$12902004000300003 \& \operatorname{lng}=e n \& n r m=i s o>$. Acesso em 20 Abril 2011. doi: $10.1590 /$ S0104-12902004000300003

AYRES, José Ricardo de Carvalho Mesquita. Sujeito, intersubjetividade e práticas de saúde. Ciênc. saúde coletiva, Rio de Janeiro, v. 6, n. 1, 2001. Disponível em: <http://www.scielo.br/scielo.php?script=sci_arttext\&pid=S141381232001000100005\&Ing=en\&nrm=iso >. Acesso em 20 Abril 2011. doi: $10.1590 /$ S1413-81232001000100005

BARROS, Marilisa Berti de Azevedo. A utilização do conceito de classe social nos estudos dos perfis epidemiológicos: uma proposta. Rev. Saúde Pública, São Paulo, v. 20, n. 4, Aug. 1986. Disponível em: <http://www.scielo.br/scielo.php?script=sci_arttext\&pid=S0034891019860004000 01\&lng=en\&nrm=iso>. Acesso em 20 Abril 2011. doi: 10.1590/S003489101986000400001

BARROS, Marilisa Berti de Azevedo. A pesquisa em Epidemiologia: dificuldades e perspectivas. Saude soc., São Paulo, v. 4, n. 1-2, 1995. Disponível em: <http://www.scielo.br/scielo.php?script=sci_arttext\&pid=S0104- 
12901995000100005\&lng=en\&nrm=iso>. Acesso em 20 Abril 2011. doi: 10.1590/S0104-12901995000100005.

CALLIGARIS, Contardo. Crônicas do Individualismo Cotidiano. São Paulo, SP: Editora Ática, 1996

CAPRARA, Andrea. Uma abordagem hermenêutica da relação saúdedoença. Cad. Saúde Pública, Rio de Janeiro, v. 19, n. 4, Aug. 2003 . Disponível em:<http://www.scielosp.org/scielo.php?script=sci_arttext\&pid=S0102311X20030 00400015\&lng=en\&nrm=iso>. Acesso em 20 Abril 2011. doi: 10.1590/S0102$311 \times 2003000400015$

DAMATTA, Roberto. A casa e a rua: espaço, cidadania, mulher e morte no Brasil. São Paulo: Editora Brasiliense, 1984.

DIAS, Ana Cristina Garcia; TEIXEIRA, Marco Antônio Pereira. Gravidez na adolescência: um olhar sobre um fenômeno complexo. Paidéia (Ribeirão Preto), Ribeirão Preto, v. 20, n. 45, Apr. 2010 . Disponível em: $<$ http://www.scielo.br/scielo.php?script=sci_arttext\&pid=S0103863X20100001000 15\&lng=en\&nrm=iso>. Acesso em 20 Abril 2011. doi: 10.1590/S0103$863 \times 2010000100015$

DUARTE, Luiz Fernando Dias; BARSTED, Leila Linhares; TAULAIS, Maria Rita; GARCIA, Maria Helena. 1993. Vicissitudes e limites da conversão à cidadania nas classes populares brasileiras Revista Brasileira de Ciências Sociais, ano 8, no 22, junho, 1993.

DUARTE, Luiz Fernando Dias. Horizontes do Individuo e da Ética no Crepúsculo da Família. In: RIBEIRO, Ivete e RIBEIRO, Ana Clara Torres. Família em Processos Contemporâneos: Inovações Culturais na Sociedade Brasileira. São Paulo: Loyola, 1995.

DUARTE, Luiz Fernando Dias. Indivíduo e pessoa na experiência da saúde e da doença. Ciênc. saúde coletiva, Rio de Janeiro, v. 8, n. 1, 2003 . Disponível em:

<http://www.scielo.br/scielo.php?script=sci_arttext\&pid=S1413812320030001000 13\&lng=en\&nrm=iso>. Acesso em 20 Abril 2011. doi: 10.1590/S141381232003000100013. 
ERDMANN, Alacoque Lorenzini et al . Gerenciando uma experiência investigativa na promoção do "viver saudável" em um projeto de inclusão social. Texto contexto - enferm., Florianópolis, v. 18, n. 2, June 2009. Disponível

em:

<http://www.scielo.br/scielo.php?script=sci_arttext\&pid=S0104070720090002000 22\&lng=en\&nrm=iso>. Acesso em 20 Abril 2011. doi: 10.1590/S010407072009000200022.

FERREIRA, Evellisse Angelica; VARGAS, leda Mara Ávila; ROCHA, Semiramis Melani Melo. Um estudo bibliográfico sobre o apego mãe e filho: bases para a assistência de enfermagem pediátrica e neonatal. Rev. Latino-Am. Enfermagem, Ribeirão Preto, v. 6, n. 4, Oct. 1998 . Disponível em: <http://www.scielo.br/scielo.php?script=sci_arttext\&pid=S0104116919980004000 14\&lng=en\&nrm=iso>. Acesso em 20 Abril 2011. doi: 10.1590/S010411691998000400014

FONSECA, Claudia. Amor e Família: Vacas Sagradas da nossa Epoca. In: RIBEIRO, Ivete e RIBEIRO, Ana Clara Torres. Família em Processos Contemporaneos: Inovacoes Culturais no Sociedade Brasileira. São Paulo: Loyola, 1995.

FONSECA, Cláudia. Crianças em circulação In: Ciência Hoje, n. 66, v.11. São Paulo: Cortez, 1990.

FONSECA, Claudia. Familia, Fofoca e Honra: Etnografia de Relacoes de Gereno e Violencia em Grupos Populares. Porto Alegre: Editora da UFRGS, 2000.

GOMES, Romeu; MENDONCA, Eduardo Alves; PONTES, Maria Luiza. As representações sociais e a experiência da doença. Cad. Saúde Pública, Rio de Janeiro, v. 18, n. 5, Oct. 2002. Disponível em: <http://www.scielo.br/scielo.php?script=sci_arttext\&pid=S0102311X20020005000 13\&lng=en\&nrm=iso>. Acesso em 20 Abril 2011. doi: 10.1590/S0102$311 \times 2002000500013$

GUIMARAES, Maria Beatriz Lisboa et al . Os impasses da pobreza absoluta: a experiência da Ouvidoria Coletiva na região da Leopoldina, Rio de Janeiro (RJ, Brasil). Ciênc. saúde coletiva, Rio de Janeiro, v. 16, n. 1, Jan. 2011. 
Disponível em:<http://www.scielo.br/scielo.php?script=sci_arttext\&pid=S141381232011000100031\&Ing=en\&nrm=iso>. Acesso em 20 Abril 2011. doi: 10.1590/S1413-81232011000100031.

GUTIERREZ, Denise Machado Duran; MINAYO, Maria Cecília de Souza. Produção de conhecimento sobre cuidados da saúde no âmbito da família. Ciênc. saúde coletiva, Rio de Janeiro, 2011 . Disponível em: <http://www.scielo.br/scielo.php?script=sci_arttext\&pid=S1413812320100007000 62\&lng=en\&nrm=iso>. Acesso em 20 Abril 2011. doi: 10.1590/S141381232010000700062 .

KASSAR, Samir B. et al . Comparações das condições socioeconômicas e reprodutivas entre mães adolescentes e adultas jovens em três maternidades públicas de Maceió, Brasil. Rev. Bras. Saude Mater. Infant, Recife, v. 6, n. 4, 2006. Disponível em: <http://www.scielo.br/scielo.phpscript=sci arttext\&pid=S151938292006000400006\&lng=en\&nrm=iso>. Acesso em 20 Abril 2011. doi: 10.1590/S1519-79722008000300008

KOBARG, Ana Paula Ribeiro; VIEIRA, Mauro Luis. Crenças e práticas de mães sobre o desenvolvimento infantil nos contextos rural e urbano. Psicol. Reflex. Crit., Porto Alegre, v. 21, n. 3, 2008. Disponível em: <http://www.scielo.br/scielo.php?script=sci_arttext\&pid=S0102797220080003000 08\&lng=en\&nrm=iso>. Acesso em 20 Abril 2011. doi: 10.1590/S010279722008000300008

LANGDON, Esther Jean; WIIK, Flávio Braune. Anthropology, health and illness: an introduction to the concept of culture applied to the health sciences. Rev. Latino-Am. Enfermagem, Ribeirão Preto, v. 18, n. 3, Jun. 2010 . Available from <http://www.scielo.br/scielo.php?script=sci_arttext\&pid=S0104116920100003000 23\&lng=en\&nrm=iso>. Acesso em 20 Abril 2011. doi: 10.1590/S010411692010000300023.

LEITE, Silvana Nair; VASCONCELLOS, Maria da Penha Costa. Negociando fronteiras entre culturas, doenças e tratamentos no cotidiano familiar. Hist. cienc. saude-Manguinhos, Rio de Janeiro, v. 13, n. 1, Mar. 2006 . Disponível em:<http://www.scielo.br/scielo.php?script=sci_arttext\&pid=S0104597020060001 
00007\&lng=en\&nrm=iso>. Acesso em 20 Abril 2011. doi: 10.1590/S010459702006000100007

LOPES, Jose Sergio Leite Coord. Cultura e Identidade Operária - Aspectos da Cultura da Classe Trabalhadora. Rio de Janeiro: Editora Marco Zero, 1987

LORDELO, Eulina Rocha et al . Investimento parental e desenvolvimento da criança. Estud. psicol. (Natal), Natal, v. 11, n. 3, Dez. 2006 . Disponível em: <http://www.scielo.br/scielo.php?script=sci_arttext\&pid=S1413294X20060003000 02\&lng=en\&nrm=iso>. Acesso em 20 Abril 2011. doi: 10.1590/S1413294X2006000300002.

MINAYO, Maria Cecília de Souza. Saúde-doença: uma concepção popular da etiologia. Cad. Saúde Pública, Rio de Janeiro, v. 4, n. 4, Dez. 1988 . Disponível em:<http://www.scielo.br/scielo.php?script=sci_arttext\&pid=S0102311X19880004 00003\&lng=en\&nrm=iso>. Acesso em 20 Abril 2011. doi: 10.1590/S0102$311 \times 1988000400003$

MONTEIRO, Carlos Augusto; FREITAS, Isabel Cristina Martins de; BARATHO, Regina Maria. Saúde, nutrição e classes sociais: o nexo empírico evidenciado em um grande centro urbano, Brasil. Rev. Saúde Pública, São Paulo, v. 23, n. 5, Outubro 1989. Disponível em: $<$ http://www.scielo.br/scielo.php?script=sci

arttext\&pid=S003489101989000500009\&Ing=en\&nrm=iso $>$. access on $20 \mathrm{Apr}$. 2011. doi: 10.1590/S0034-89101989000500009

OLIVEIRA, Alda Batista de; ROAZZI, Antonio. A representação social da "doença dos nervos" entre os gêneros. Psic.: Teor. e Pesq., Brasília, v. 23, n. 1, Março 2007. Disponível em: <http://www.scielo.br/scielo.php?script=sci arttext\&pid=S010237722007000100011\&lng=en\&nrm=iso > . Acesso em 20 Abril 2011. doi: 10.1590/S0102-37722007000100011.

OLIVEIRA, Irma de; ANGELO, Margareth. Vivenciando com o filho uma passagem difícil e reveladora: a experiência da mãe acompanhante. Rev. esc. enferm. USP, São Paulo, v. 34, n. 2, Junho 2000 . Disponível em: $<$ http://www.scielo.br/scielo.php?script=sci_arttext\&pid=S0080623420000002000 10\&lng=en\&nrm=iso>. Acesso em 20 Abril 2011. doi: 10.1590/S008062342000000200010 
PERSONA, Lia; SHIMO, Antonieta Keiko Kakuda; TARALLO, Maria Celina. Perfil de adolescentes com repetição da gravidez atendidas num ambulatório de pré-natal. Rev. Latino-Am. Enfermagem, Ribeirão Preto, v. 12, n. $5, \quad$ Out. 2004 Disponível em: <http://www.scielo.br/scielo.php?script=sci_arttext\&pid=S0104116920040005000 07\&lng=en\&nrm=iso>. Acesso em 20 Abril 2011. doi: 10.1590/S010411692004000500007

RESSEL, Lucia Beatriz et al . Representações culturais de saúde, doença e vulnerabilidade sob a ótica de mulheres adolescentes. Esc. Anna Nery, Rio de Janeiro, v. 13, n. 3, Setembro 2009 . Disponível em: $<$ http://www.scielo.br/scielo.php?script=sci_arttext\&pid=S1414814520090003000 14\&lng=en\&nrm=iso>. Acesso em 20 Abril 2011. doi: 10.1590/S141481452009000300014

SANTOS, Sílvia Reis dos; SCHOR, Néia. Vivências da maternidade na adolescência precoce. Rev. Saúde Pública, São Paulo, v. 37, n. 1, Fev. 2003. Disponível em: <http://www.scielo.br/scielo.php?script=sci_arttext\&pid=S003489102003000100005\&Ing=en\&nrm=iso $>$. Acesso em 20 Abril 2011. doi: 10.1590/S0034-89102003000100005.

SIQUEIRA, Liamara da Silva; SIGAUD, Cecilia Helena de Siqueira; REZENDE, Magda Andrade. Fatores que apoiam e não apoiam a permanência de mães acompanhantes em unidade de pediatria hospitalar. Rev. esc. enferm. USP, São Paulo, v. 36, n. 3, Setembro 2002 . Disponível em: <http://www.scielo.br/scielo.php?script=sci_arttext\&pid=S0080623420020003000 09\&lng=en\&nrm=iso>. Acesso em 20 Abril 2011. doi: 10.1590/S008062342002000300009 .

TAVARES, Márcia Santana. Com açúcar e sem afeto: a trajetória de vida amorosa de mulheres das classes populares em Aracaju/SE. Serv. Soc. Soc., São Paulo, n. 101, Março 2010. Disponível em: <http://www.scielo.br/scielo.php?script=sci_arttext\&pid=S0101662820100001000 07\&lng=en\&nrm=iso>. Acesso em 20 Abril 2011. doi: 10.1590/S010166282010000100007.

VASCONCELOS, Maria Gorete Lucena de; LEITE, Adriana Moraes; SCOCHI, Carmen Gracinda Silvan. Significados atribuídos à vivência materna como 
acompanhante do recém-nascido pré-termo e de baixo peso. Rev. Bras. Saude Mater. Infant., Recife, v. 6, n. 1, Março 2006 . Disponível em: <http://www.scielo.br/scielo.php?script=sci_arttext\&pid=S1519382920060001000 06\&lng=en\&nrm=iso>. Acesso em 20 Abril 2011. doi: 10.1590/S151938292006000100006.

VELHO, Gilberto. Individualismo e Cultura: Notas para uma Antropologia da Sociedade Contemporânea. Rio de Janeiro: Jorge Zahar, 1987 